\title{
ARTIKKELIT
}

\section{Yksinäisyys kotona asuvien iäkkäiden elämässä}

\author{
Ritva Kangassalo ${ }^{1}$, Sari Teeri ${ }^{2}$ \\ Satakunnan Vanhustuki ry ${ }^{1}$, Satakunnan ammattikorkeakoulu ${ }^{2}$
}

\begin{abstract}
Tässä artikkelissa kuvataan kotona asuvien iäkkäiden ihmisten kokemuksia yksinäisyydestään. Tutkimus on osa Satakunnan Vanhustuki ry:n Yksinäisyydestä aitoon kohtaamiseen -hanketta. Aineisto kerättiin haastattelemalla kymmentä, hankkeen ensimmäisen puolen vuoden aikana tavattua asiakasta. Haastattelut toteutettiin avoimina ja keskustelunomaisina. Ne nauhoitettiin, ja niistä pidettiin päiväkirjaa. Aineisto analysoitiin induktiivisesti teema-analyysillä. Haastateltavien keski-ikä oli 85 vuotta. He olivat yksin asuvia, leskeytyneitä, ja useimmat heistä olivat muuttaneet lähiaikoina uuteen asuinympäristöön. Heidän sosiaaliset suhteensa olivat harventuneet, terveys ja toimintakyky alentunut, ja lähes kaikilla oli ollut elämänhistoriassa haavoittavia kokemuksia. Yksinäisyyden kokemus vaihteli jatkuvasta yksinäisyydestä ajoittaiseen. Se ilmeni sekä emotionaalisena että sosiaalisena yksinäisyytenä. Osa haastateltavista korosti ihmisen omaa vastuuta elämästään ja myös yksinäisyydestään. Enemmistö heistä toivoi yksinäisyyteen apua ulkopuoliselta taholta, esimerkiksi asuinyhteisöltä, ystäviltä tai tuttavilta. Tulosten mukaan yksinäisyyteen yhteydessä olevien tekijöiden kasautuminen aiheuttaa yksinäisyyden kokemuksen. Haasteeksi yksinäisyyden lievittämiseen tähtäävissä interventioissa tulee näiden ikäihmisten uudelleen aktivointi ja elämänpiirin laajentaminen osallistaviin toimintoihin ja sosiaalisiin suhteisiin. Näitä interventioita tullaan tässä hankkeessa kehittämään yhdessä iäkkäiden henkilöiden kanssa.
\end{abstract}

\section{Johdanto}

Yksinäisyys on keskeinen haaste vanhustyössä. Tutkimusten mukaan ikääntyessä ihmisen kokemus yksinäisyydestä lisääntyy (Luo, Hawkley, Waite \& Cacioppo 2012; Honigh-de Vlaming 2014) kasautuen erityisesti 85 vuotta täyttäneille (Vaarama, Mukkila \& HannikainenIngman 2014). Ikä sinänsä ei kuitenkaan selitä yksinäisyyttä vaan ikääntymiseen ja elämänkulkuun tyypillisesti kuuluvat tapahtu- mat (Heylen 2010; Honigh-de Vlaming, Haveman-Nies, Heinrich, van der Veer \& de Groot 2013; Tiilikainen 2016). Yleisimpiä yksinäisyyden kokemiseen yhteydessä olevia tekijöitä ovat eläkkeelle jääminen, leskeys, sosiaalisten suhteiden puuttuminen, muutto, traumaattiset elämäntapahtumat, terveysongelmat, toimintakyvyn lasku ja huono taloudellinen tilanne (Dahlberg \& McKee 2013; Tiilikainen 2016). Yksinäisyyden tunteeseen liittyy elämän kokeminen merkityksettömäksi ja leimautumi- 
sen pelko. Yksinäisyys voi olla myös uuvuttava kokemus yhteiskunnallisesta osattomuudesta. (Tiilikainen 2016.)

Yksinäisyys on noussut merkittäväksi tutkimuskohteeksi siihen liittyvien negatiivisten yhteyksien vuoksi. Se on elämänlaatua heikentävä, kivulias, lohduttomuutta, surua, synkkyyttä ja kärsimystä tuottava tunne (Weiss 1973). Ihminen kokee olevansa toisten unohtama ja ulkopuolinen. Kokemukseen liittyy usein sosiaalisten suhteiden vähäisyys ja yhteydenpidon niukkuus lapsiin ja lastenlapsiin. Kuitenkin kokemus yksinäisyydestä voi olla riippumaton siitä, onko ympärillä muita ihmisiä (Victor, Scambler \& Bon 2009; Pirhonen, Tiilikainen \& Lemivaara 2016). Joidenkin tutkimusten mukaan yksinäisyyden nähdään olevan ihmisen omaa syytä, ja että se on seurausta kontakteista vetäytymisestä ja itseensä keskittymisestä (Kirkevold, Moyle, Wilkinson, Meyer \& Hauge 2012) sekä kriittisestä persoonallisuudesta (Hauge \& Jirkevold 2010).

Yksinäisyys on subjektiivinen kokemus, jolla on ajallinen luonne. Se voi olla jatkuvaa tai ajoittaista. Ajoittaiseen yksinäisyyteen vaikuttavat vuorokauden- ja vuodenajat. Yksinäisyyden tunne vahvistuu usein erityisesti juhlapyhinä.(mm. Pajunen 2011; Tiilikainen 2016.) Yksinäisyyden ajallisuus tulee esille sen sosiaalisessa ja emotionaalisessa ulottuvuudessa. Sosiaalinen yksinäisyys ilmenee nykyhetkessä, sosiaalisten suhteiden, lähipiirin ja yhteenkuuluvuuden tunteen puuttumisessa. Sosiaaliset suhteet korostuvat yhtenä hyvinvoinnin osatekijänä vahvistaen sosiaalista identiteettiä (Levasseur, Richard, Gauvin \& Raymond 2010; Dahlberg \& McKee 2014). Emotionaalisen yksinäisyyden taustalla on läheisen ihmissuhteen ja kiintymyksen kohteen puuttuminen tai sen menettäminen. Tällöin yksinäisyyttä ei välttämättä voi poistaa muu kuin uusi emotionaalisesti läheinen suhde. (Weiss 1973.) Emotionaalisen yksinäisyyden aiheuttaman negatiivisen tunteen on todettu vahvistuvan erityisesti iltaisin ja öisin (mm.
Tiilikainen 2016). Naisten on todettu kokevan emotionaalista yksinäisyyttä jonkin verran miehiä enemmän (Dahlberg \& McKee 2014).

Yksinäisyyden lievittämiseksi on kehitetty erilaisia interventioita. Interventioiden tavoitteena on ollut sosiaalisten taitojen parantaminen, sosiaalisen tuen ja kontaktien lisääminen. Tyypillisimpiä muotoja ovat ryhmissä tapahtuvat aktiviteetit. Ryhmien tavoitteena on sosiaalisen aktiivisuuden ja kontaktien lisääminen. Ryhmät rakentuvat yleensä tietyn toiminnan tai keskusteluteeman ympärille. Myös kahdenkeskisiä keskusteluja ja kotikäyntejä on käytetty. (Savikko 2008; Masi, Chen, Hawkley \& Cacioppo 2011.) Erityisesti sosiaalisilla ryhmillä on todettu olevan jonkin verran vaikutusta yksinäisyyden vähenemiseen. Esimerkiksi Vanhustyön keskusliitto on kehittänyt ja toteuttanut ystäväpiiritoimintamallia eri puolilla Suomea yli kymmenen vuoden ajan. Mallissa koulutetut ryhmänohjaajat tapaavat ystäväpiiriin valittuja osallistujia 12 kertaa. Ystäväpiiri perustuu vertaistukeen ja yhteyden jatkumiseen osallistujien välillä ryhmätoiminnan päättymisen jälkeen. Osallistujista suurin osa (86 \%) on kokenut yksinäisyytensä lieventyneen, ja yli puolet on ystävystynyt jonkun ryhmäläisen kanssa. Osallistujat ovat myös kokeneet saaneensa ideoita ja näköaloja omaan elämäänsä. (Savikko 2008; Jansson 2012; PitkäläRoutasalo 2012; Mervilä-Puhakka 2015.)

Parhaiten toimiviksi yksinäisyyden lievittäjiksi on todettu ryhmät, joiden interventioissa on teoreettinen perusta ja joiden toiminnassa ikäihmiset ovat aktiivisesti mukana (Dickens, Richards, Colin, Greaves \& Campbell 2011). Interventioiden pidempiaikaisia vaikutuksia on selvitetty vähemmän, ja joidenkin tutkimusten mukaan vaikutusten ei ole todettu olevan pysyviä (esim. Honigh-de Vlaming ym. 2013). On myös kuvattu yksinäisyyden tunteen katoavan vasta kun henkilön tyydyttämättömät tarpeet tulevat tyydytetyiksi (Heinrich \& Gullone 2006). 


\section{Aineisto ja menetelmät}

Tutkimuksen tarkoituksena oli kuvata Satakunnan Vanhustuki ry:n Yksinäisyydestä aitoon kohtaamiseen 2016-2018 -hankkeen asiakkaiden kokemuksia yksinäisyydestään. Tavoitteena oli tuottaa tietoa yksinäisyyden lievittämiseen tähtäävien interventioiden kehittämiseksi.

Tutkimuskohteena olivat Satakunnan Vanhustuki ry:n hallinnoiman, 1.3.2016 käynnistyneen Yksinäisyydestä aitoon kohtaamiseen 2016-2018 -hankkeen toiminnan ensimmäisen puolen vuoden aikana tavatut asiakkaat. Asiakkaat olivat ottaneet yhteyttä itse tai valtuuttaneet jonkun läheisensä ottamaan yhteyttä käynnistyneeseen yksinäisyys-projektiin. Projektityöntekijät valitsivat kotona asuvista ja yksinäisiksi itsensä kokevista asiakkaistaan haastateltavat. Valintakriteerinä oli työntekijöiden arvioima yksinäisyys sekä asiakkaan suostumus haastatteluun. Haastateltavat eivät olleet kotihoitopalvelujen säännöllisiä käyttäjiä. Tutkimuslupa saatiin Satakunnan Vanhustuki ry:n hallitukselta. Aineisto hankittiin keskustelunomaisesti avoimina haastatteluina, jotka nauhoitettiin. Haastattelija oli projektin ulkopuolinen henkilö, eikä ollut tavannut haastateltaviaan aikaisemmin.

Aineiston hankintamenetelmäksi valittiin keskustelunomainen avoin haastattelu, koska sen avulla haastateltavilla oli mahdollisuus kertoa omia kokemuksiaan ja näkemyksiään yksinäisyydestään (mm. Aronson 1994; Laine 2001; Burns \& Grove 2005). Kun tutkitaan subjektiivisia kokemuksia, ei kvantitatiivisella mittarilla tai etukäteen suunnitelulla kysymyssarjalla tavoiteta yksittäisen ihmisen kokemusmaailmaa (Vanhatalo 2016). Tässä tutkimuksessa tiedonantajat olivat pääosassa, ja he kertoivat haastattelijalle omia kokemuksiaan, omilla sanoillaan. Haastatteluista pidettiin myös haastattelupäiväkirjaa, jota käytettiin tulosten analysoinnin tukena.

Haastatteluun suostuneihin otettiin puhelinyhteys ja sovittiin haastatteluaika. Tämän artikkelin ensimmäinen kirjoittaja toteutti haastattelut. Kuusi haastattelua tapahtui haastateltavan kotona ja neljä haastateltavan toivomuksesta Satakunnan Vanhustuki ry:n toimistohuoneessa. Haastattelun alussa pyydettiin kirjallinen suostumus ja kerrottiin, että haastattelun tarkoituksena on keskustella yksinäisyydestä haastateltavan elämässä. Ensimmäiset kolme haastattelua toteutettiin kahtena tapaamiskertana, joista ensimmäinen käytettiin tutustumiseen. Tarkoituksena oli, että tällä tavoin toisella kerralla voitaisiin arasta yksinäisyyden aiheesta keskustella avoimemmin. Käytäntö ei tukenut tätä tarkoitusta, sillä jo ensimmäisellä kerralla haastateltavat kertoivat yksinäisyydestään saman, mikä tuli esille varsinaisessa tutkimushaastattelussa. Tämän jälkeen tutkija tapasi seuraavat haastateltavat vain yhden kerran. Haastattelujen kesto vaihteli runsaasta tunnista kahteen tuntiin. Nauhoitetut osuudet haastatteluista vaihtelivat 32 minuutista 45 minuuttiin. Haastattelut olivat runsaita, ja pysyminen sovitussa aiheessa oli lähes jokaisessa haastattelussa vaikeaa. Haastatelluilla oli tarve puhua elämästään, kertoa itsestään, ajatuksistaan ja yksinäisyydestään.

Aineisto analysoitiin aineistolähtöisesti, koska tarkoituksena oli kuvata haastateltujen omia kokemuksia (Tuomi \& Sarajärvi 2004). Analyysi aloitettiin kuuntelemalla haastattelujen nauhoitukset useampaan kertaan ja lukemalla samalla haastatteluun liittyvä osuus haastattelupäiväkirjasta. Haastatteluaineiston täydentäminen haastattelupäiväkirjalla rikastuttaa aineistoa (Silverman 2000). Haastatteluista poimittiin yksinäisyyteen liittyviä lausumia kunkin haastateltavan nimen (nimet muutettu) alle. Sen jälkeen aineisto ryhmiteltiin teema-analyysina, joka soveltuu kokemuksista kertovan puheen analyysimenetelmäksi (Aronson 1994).

\section{Kuvaus tutkimukseen osallistuneista}

Haastateltavat olivat kotona yksin asuvia ikääntyneitä. Heistä seitsemän oli naisia ja 
kolme miehiä. Nuorin heistä oli 82- ja vanhin 88-vuotias. Seitsemän haastateltavaa asui kerrostaloasunnossa ja kolme omakotitalossa. Kahdeksan heistä oli jäänyt leskeksi. Omakotitalossa asuvat olivat jääneet leskiksi vasta vähän aikaa sitten, viiden kerrostalossa asuvan haastateltavan puolison kuolemasta oli kulunut enemmän aikaa. Kerrostalossa asuvista yksi henkilö oli eronnut vuosikymmeniä sitten ja yhden puoliso oli elossa, mutta ollut pitkäaikaisessa laitoshoidossa useita vuosia. Kaikilla haastatelluilla oli lapsia, ja lasten lukumäärä vaihteli yhdestä kolmeen. Viiden haastateltavan lapset asuivat kauempana, osa hyvinkin kaukana (esimerkiksi Amerikassa). Muiden lapset asuivat samassa kaupungissa tai melko lähellä ja olivat yhteyksissä vanhempiinsa säännöllisesti tai melko usein.

Kaikkien haastateltavien elämään sisältyi myös vaikeita elämänkokemuksia. Tällaisia olivat muun muassa perheessä pitkään asunut vaikea puolison vanhempi, lapsuuden huono-osaisuus, perintöriidat, lapsen kuolema nuorena aikuisena, puolison itsemurha, väkivaltainen alkoholismia sairastava puoliso, lasten ongelmat ja laitoshoidossa oleva puoliso.

Kaikki haastateltavat olivat olleet työikäisinä kodin ulkopuolella töissä: teollisuudessa, palveluammateissa, toimistotöissä tai virkamiehenä. Useimmilla oli pitkiä työsuhteita, osa oli ollut lasten ollessa pieniä muutaman vuoden kotona, osa oli vaihtanut työpaikkaa useampia kertoja työuransa aikana. Eläkkeelle oli jääty eläkeiässä, vain yksi haastatelluista oli jäänyt sairaseläkkeelle tapaturman seurauksena.

Kaikki haastateltavat olivat muuttaneet asuinpaikkaa jossain elämänsä vaiheessa. Osalla heistä oli taustalla lyhempiä muuttoja, paikkakunnan ja maakunnan sisällä hyvinkin moneen kertaan. Kaksi heistä oli syntynyt Karjalassa, josta oli joutunut lähtemään evakkoon kahteenkin kertaan. Kaksi haastatelluista oli asunut työikänsä pääkaupunkiseudulla ja muuttanut takaisin lapsuuspaikkakunnalleen vasta eläkeläisenä. Yksi haastatelluista oli kahdenkymmenen vuoden ajan asunut puolisonsa kanssa talvet Espanjassa, ja nyt puolison kuoltua jäänyt talveksi Suomeen.

\section{Tulokset}

Aineisto ryhmiteltiin kolmeen teemaan: yksinäisyyteen yhteydessä olevat muutokset haastateltavan elämässä, kokemus yksinäisyydestä omassa elämässä ja yksinäisyyden torjuminen. Yksinäisyyteen yhteydessä olevat muutokset haastateltavan elämässä jakautuivat asuin- ja elinympäristön muutoksiin, terveyden ja toimintakyvyn muutoksiin ja muutoksiin sosiaalisissa suhteissa. Kokemus yksinäisyydestä omassa elämässä jakautui yksinäisyyden tunteeseen ja ihmissuhteiden merkitykseen yksinäisyydessä. Yksinäisyyden torjuminen -teema jakautui omavastuisuuteen ja muiden ihmisten tukeen. Tulosten esittämisessä käytetään suoria lainauksia haastatteluista kuvaamaan ilmiötä sellaisena kuin haastateltavat sen kuvasivat (Silverman 2000; Burns \& Grove 2005).

\section{Yksinäisyyteen yhteydessä olevat muutokset haastateltavan elämässä}

Kaikki haastateltavat kokivat vanhenemisen tuoneen muutoksia elämäänsä. Muutokset eivät olleet vanhenemisen sinänsä aiheuttamia, vaan elämäntilanteessa, terveydessä tai toimintakykyisyydessä tapahtuneita muutoksia. Näissä haastatteluissa nousi esille lähiaikoina haastateltavan elämässä tapahtuneiden muutosten yhteys elämänlaadun heikkenemiseen ja yksinäisyyteen.

\section{Asuin- ja elinympäristöön liittyvät muutokset}

Kerrostaloasunnossa asuvista haastatelluista vain yksi oli asunut nykyisessä asunnossaan pidemmän aikaa, sen valmistumisesta lähtien. Muilla kerrostaloon muuttaminen oli tapahtunut jonkin aikaa sitten, isommasta asunnosta pienempään tai omakotitalosta kerrostaloon. He olivat periaatteessa tyytyväisiä ratkaisuihin- 
sa, mutta ongelmiksi koettiin huono esteettömyys (esim. jyrkät raput ulkorappusilta hissitasanteelle) ja vaikeus tutustua uuden asuintalon ja -alueen ihmisiin. Uusi asuinympäristö oli osaltaan lisännyt heidän kokemustaan yksinäisyydestä. Tutut naapurit ja asuinyhteisö oli jäänyt, vaikka asuttiin samassakin kaupungissa.

Ulos meneminen on ongelma, vaikka tässä talossa on hissi, niin ensimmäisestä kerroksesta on kuitenkin toistakymmentä melko jyrkkää rappusta pihamaalle. Luiskaa ei ole. Pohjakerroksen kautta pääsee ulos helpommin, sieltä on vain viisi rappua pihamaalle ja siellä on kapea pyörille rakennettu luiska, johon ei pyörätuoli mabdu. (Meeri)

Kerrostalon ylimmässä kerroksessa asuva Tyyne kertoi, ettei kahteen vuoteen kukaan hänen asuintalostaan ollut soittanut hänen ovikelloaan. Elman mukaan:

Menee useita päiviä, että en pubu tai tapaa silmäkkäin ibmisiä. Kyllä sitä saisi ibmisten näkemistä olla enemmänkin. Pibamaalla on puutarhapenkki, johon menen joskus istumaan ja katselemaan elämää. Joskus tulee joku viereenkin istumaan ja jutellaan.

Omakotitalossa asuvien haastateltujen puolisojen kuolemasta oli kulunut vasta melko vähän aikaa. Yhden haastatellun lapset olivat ehdottaneet omakotitalon myymistä ja muuttamista kerrostaloon, toiset omakotitaloasujat olivat ainakin toistaiseksi päättäneet"asua kotonaan". He olivat järjestäneet omakotitaloon liittyvät työt niin, että joko he itse tai sovittu/palkattu henkilö hoiti esimerkiksi ruohikonleikkuun ja lumen kolauksen.

Aluksi tänne muutettua asuttiin vuokralla kerrostaloissa. Elettiin säästäväisesti ja tebtiin kovasti töitä ja sitten saatiin tämä omakotitalotontti ostettua ja rakennettiin tämä talo. Ja tässä haluan asua, vaikka asunkin nyt puolison kuoltua yksin. (Väinö)
Asun kuitenkin samassa kodissa, jossa olenkin asunut - mielestäni on tärkeää että asun omassa kodissani. Niin kauan kuin olen toimintakykyinen asun kotonani - siivoja minulla käy, ruokapalvelua otan kolme kertaa viikossa, olen tyytyväinen olemiseeni. (Meeri)

Puolison kuolema oli tuonut omakotitalossa asuvien elämään yksinäisyyden, vaikka he halusivatkin jatkaa asumista omassa kodissaan ja elinympäristössään. Yhdessä rakennettu tai hankittu talo koettiin tärkeäksi, samoin kuin tuttu asuinyhteisö.

\section{Terveyteen ja toimintakykyyn liittyvät muutokset}

Haastatteluissa tuli esille terveyteen ja toimintakykyyn liittyviä ongelmia, joiden koettiin osaltaan vaikuttaneen yksinäisyyttä lisäävästi. Osa tuntui sopeutuneen sairauksiinsa ja koki selviävänsä niiden kanssa, vaikka ei voinutkaan enää samalla tavalla liikkua ja osallistua kuin aikaisemmin. Meeri oli joutunut kaksi vuotta sitten aivoverenvuodon seurauksena pyörätuoliin, osalla oli vaikeitakin sydänsairauksia, hoidettu syöpäsairaus, silmänpohjarappeumaa, ruoansulatuselinten ongelmia tai työtapaturmainen selkäongelma, joka oli iän myötä pahentunut. Näiden sairauksien koettiin vaikeuttavan osallistumista mm. liikkumisvaikeuksien, heikentyneen näön tai hallitsemattomien vatsantoimintaongelmien vuoksi.

Kaksi haastatelluista kertoi, että heillä oli diagnosoitu Alzheimerin tauti. Toinen heistä sai siihen lääkitystä ja oli tehnyt edunvalvontavaltuutuksen. Hän myös suunnitteli omaistensa kanssa yhteistyössä palveluasumiseen muuttamista. Toinen muistisairaista tunnisti itse muistinsa huonontuneen, ja sen havaitsi myös haastattelun kuluessa. Haastattelun kuluessa selvisi, että hän ei ollut muistiongelmiensa vuoksi käynyt lääkärissä tai muistitesteissä, eikä hänen muistiongelmiaan ollut diagnosoitu. Hänet ohjattiin haastattelun jälkeen tutkimuksiin ja hoitoon. Kolmas haastateltava toivoi pääsevänsä muistiongelmien vuoksi laitos- 
hoitoon, mutta harmitteli olevansa liian terve siihen. Hän oli useitakin kertoja käynyt muistitesteissä, muistihoitajalla ja lääkärillä. Hän koki, että laitosasuminen olisi lisännyt hänen turvallisuuttaan.

Kun keskustelimme osallistumisen ja yhteydenpidon muutoksista haastateltujen omassa elämässä, terveys ja toimintakyky nousivat selittäviksi tekijöiksi. He kertoivat "tulleensa saamattomiksi”, oli alkanut huimailla, ja kaatuminen oli alkanut pelottaa. Osalla haastatelluista oli vakaviakin sairauksia, ja he kertoivat hoitavansa itseään parhaansa mukaan ja ottavansa sairauksien tuomat rajoitukset huomioon elämässään. Yhteydenpidon vaikeutumisen koettiin vähentäneen sosiaalisia kontakteja ja osaltaan lisänneen yksinäisyyttä.

\section{Sosiaalisiin suhteisiin liittyvät muutokset}

Haastateltavista kahdeksan oli leskiä,joista yksi oli eronnut ensimmäisestä avioliitostaan, mutta ollut sen jälkeen naimisissa ja tämä toinen puoliso oli kuollut. Lisäksi yksi haastateltava oli eronnut, ja yhden puoliso oli pitkäaikaisessa laitoshoidossa. Jokaisella haastatellulla oli kokemus puolison ja lasten kanssa asumisesta, nyt lapset olivat aikuistuneet, muuttaneet pois lapsuuskodistaan ja perustaneet omat perheensä. Suhteet lapsiin olivat haastateltujen mukaan hyvät, intensiteetti vaikutti kuitenkin vaihtelevan. Yksi haastatelluista kävi lapsensa kanssa kaupassa viikoittain, muiden kohdalla säännöllinen avustaminen ei tullut esille. Kauempana oleviin lapsiin oltiin puhelinyhteydessä joku jopa päivittäin. Lasten koettiin tukevan ja kuuntelevan vanhempiaan. Lapsiperheen supistuminen ensin kahden henkilön ja lopulta yhden henkilön perheeksi koettiin olevan yhteydessä yksinäisyyteen.

Lasten kanssa on hyvät välit ja lastenlapsiin. (Veera)

\section{Kaipaan kyllä lapsia - joskus toivon että he} olisivat lähempänä. (Tyyne)
Kuudella haastatelluista oli sisarus tai useampia elossa, ja kahdella heistä oli tiivis yhteys sisaruksiinsa, yhdellä oli yhteys viikoittain ja kolme oli yhteydessä silloin tällöin. Esille tuli myös ongelmallisia sisarussuhteita, joissa yhteydenpito oli katkennut. Sisarusten kanssa pidettiin yhteyttä useimmiten puhelimitse, ja etäisyydet vaikeuttivat tapaamisia. Tiiviin yhteyden sisaruksiin kerrottiin lievittävän yksinäisyyttä.

Sukulaisia ja tuttavia asuu lähellä-ja käyvät nekin ja pitävät huolta... (Labja)

Lastenlapset eivät kovinkaan merkittävästi nousseet haastatteluissa esille. Yhdellä oli hoitoalan koulutuksen saanut lapsenlapsi, joka kävi auttamassa isovanhempaansa viikoittain ja johon isovanhempi tarpeen mukaan oli yhteydessä muutenkin.

Nuoruuden ystävät olivat jo kuolleet. Erityisesti Tyyne kaipasi kuollutta ystäväänsä,jonka kanssa hän oli aikaisemmin osallistunut monenlaisiin kulttuuriharrastuksiin ja käynyt kävelylenkeillä. Väinö kertoi tapaavansa "naapurin miehen" kanssa melkein päivittäin ja koko asuinyhteisön olevan hyvä. Lisäksi Väinö kertoi:

Eläkeläisten toiminnassa käyn - tappamassa aikaa ja tapaamassa entisiä työkavereita. Karjalaisten tapaamisissa käyn joka kuukausi. Ja kauppakeskuksessa meitä on muutaman miehen porukka, jotka näemme muutaman kerran viikossa ja parannamme maailmaa.

Kukaan haastatelluista ei tuonut esille, että ns. paras ystävä tai hyvä ystäväporukka olisi olemassa. Osalla oli kuitenkin muutaman "tuttavan" ryhmä, joiden kanssa tavattiin aika ajoin ja voitiin mennä erilaisiin tapahtumiin ja tilaisuuksiin yhdessä. Jotkut haastatellut korostivat, että he voivat mennä tilaisuuksiin yksinkin, jotkut taas kokivat luontevammaksi mennä yhdessä toisen kanssa. Sosiaalisten suhteiden muuttuminen ja harveneminen tuli tässä haastattelussa esille, ja tämän myönnettiin vaikuttavan itsensä yksinäiseksi kokemiseen. 
Kokemus yksinäisyydestä omassa elämässä

Osa haastatelluista kertoi tuntevansa itsensä yksinäiseksi päivittäin, osa myönsi tuntevansa yksinäisyyttä silloin tällöin, ja mukana oli myös kaksi henkilöä, jotka kielsivät yksinäisyyden. He olivat kuitenkin itse ottaneet yhteyden yksinäisyys-projektin työntekijöihin ja kertoneet olevansa yksinäisiä.

\section{Yksinäisyyden tunne}

Yksi haastatelluista kertoi tunteneensa itsensä aikaisemminkin elämässään sivustakatsojaksi, mutta olleensa sellainen ihminen, jolle monet tuttavat ovat halunneet uskoutua ja kertoa ongelmistaan: olin sellainen byvä kuunteli$j a$. Toinen kertoi hyvin yksinäisestä ulkopuolisuuden kokemuksestaan ja vaikeasta lapsuudestaan ollessaan sijoitettuna kasvattiperheessä.

Kaksi haastatelluista ei myöntänyt kokevansa itseään yksinäiseksi, vaikka he olivat molemmat itse ottaneet yhteyttä yksinäisyys-projektin työntekijöihin ja olivat suostuneet haastateltaviksi yksinäisyydestään. Toinen heistä nimesi tuntemuksensa "pitkäksi ajaksi" ja kertoi, että on välillä kovin pitkä aika, vaikka yhteydenpitoa lasten ja sukulaisten taholta on lähes päivittäin. Toinen yksinäisyytensä kieltävistä kertoi, että jos sitä kokisi itsensä yksinäiseksi, se olisi peiliin katsomisen paikka. Yksinäisyyden tunnustamisen kynnys vaikutti heidän kohdallaan olevan korkea.

Yksinäisyys oli tullut kahdeksan haastatellun elämään vasta viime vuosina, joku myönsi tuntevansa itsensä yksinäiseksi päivittäin, useimmat aika ajoin. Yksinäisyyden kerrottiin olevan negatiivinen tunne, joka "vain tulee".

Joskus on kuitenkin sellaisia hetkiä. Se tunne tulee silloin kun tulee. Yksinäisyys on tunne... on aivan yksin. (Tyyne)

Yksinäinen on yksinäinen, ja se on pabaa oloa. On tullut tyhjyys... tarkoituksettomuus ja tarpeettomuus. (Elma)
Joskus tulee pitkä aika ja yksinäinen olo, tippa linssiin. Tulee katkera olo. Se yksinäisyys on semmoinen haikea olo. (Meeri)

\section{Ihmissuhteiden merkitys yksinäisyyden kokemukseen}

Haastatteluissa korostui ihmissuhteiden muuttumisen ja vähenemisen merkitys yksinäisyyteen. Haastateltavat kertoivat yksinäisyyden kokemuksen ja sosiaalisten suhteiden muutosten välisestä yhteydestä. Kaikissa haastatteluissa tuotiin esille elämänvaiheita, joihin olivat kuuluneet niin puoliso, kotona asuvat lapset kuin työtoveritkin. He olivat osallistuneet ja harrastaneet toimintoja, joihin oli sisältynyt muiden ihmisten tapaamista ja ryhmäytymistä. Nämä elämää rikastuttaneet sosiaaliset suhteet olivat muuttuneet ikääntyessä, ja sosiaalisten suhteiden määrä oli kaikilla vähentynyt.

Arkeni on hyvin yksinäistä. Olimme melkein aina mieheni kanssa ybdessä. (Vieno)

Olen aika ajoin yksinäinen. Vieraiden lähtiessä tulee haikea mieli... (Maire)

Olen aina yksinäinen, kuoroissa lauloin yli 20 vuotta, nyt ei enää... (Tauno)

Haastatellut kertoivat, ettei yksinäisyys ollut aikaisemmin kuulunut heidän elämäänsä, mutta nyt vanhana yksinäisyys oli hiipinyt elämään. He tunnistivat ihmissuhteiden vähenemisen yksinäisyyttä lisääväksi tekijäksi.

Kun sitä on yksin, tulee niin araksi, ettei sitä uskalla enää mibinkään läbteäkään. Aikaisemmin elämässä en ollut yksinäinen, vasta tässä parin vuoden aikana. (Elma)

...kun sitä oli työelämässä, oli siihen liittyviä kontakteja, ei ollut yksinäinen. (Tyyne)

Haastatelluilla oli työikäisinä ollut sellaisia harrastuksia, joista he olivat terveyden ja toimintakyvyn muutosten takia joutuneet luopu- 
maan. Harrastukset olivat tuoneet elämään sosiaalisia suhteita ja monenlaista toimintaa. Yksi haastatelluista kertoi olleensa koiraharrastaja, jonka elämään oli tuonut sisältöä näyttelyt ja pentukasvatus. Kaksi haastateltua olivat olleet aktiivisia vapaaehtoistyöntekijöitä ja mukana monenlaisessa toiminnassa. He kertoivat miten muiden auttaminen oli tuonut omaankin elämään merkitystä ja sisältöä. Yhden elämänsisältönä oli ollut kuoroharrastus. Hän kertoi rakastavansa musiikkia, mutta kuoro toi elämään myös kaveriryhmän ja esiintymisiä.

Haastateltavat kertoivat arkensa toistuvan samanlaisena. Siihen sisältyivät päivittäiset arkirutiinit ja pienet arkiaskareet. Useimmilla oli oman kokemuksensa mukaan liian vähän kohtaamisia muiden ihmisten kanssa. Kaksi haastateltavaa tapasi ainakin ateriapalvelun tuojan viitenä päivänä viikossa, yhdelle soitettiin arkipäivisin vapaaehtoistoiminnan keskuksesta "tarkistuspuhelu", ja kahden haastateltavan lapset soittivat päivittäin. Haastateltavat kertoivat viettävänsä aikaa televisiota katsellen ja radiota kuunnellen. Yksi haastatelluista kertoi olleensa ahkera kirjastossa kävijä, mutta toimintakyvyn heikkeneminen oli lopettanut sen. Yksi haastatelluista teki päivittäin käsitöitä. Päivälehdet luettiin ja katseltiin ikkunasta tai istuskeltiin sään salliessa parvekkeella tai pihapenkillä. Viisi haastatelluista kertoi pyrkivänsä ulkoilemaan päivittäin tai useita kertoja viikossa. Arkeen kuitenkin toivottiin lisää muiden ihmisten tapaamisia ja toimintaa, ja tapahtumaköyhä arki koettiin yksinäisyyden tunnetta lisääväksi.

Joka arkipäivä näen ainakin ruoan tuojan, ovat kivoja poikia. Ebtivät muutaman sanan jutellakin. Iltapäivällä saatoin aikaisemmin käydä ulkona, mutta nykyisin ei juuri. ... Parvekkeella pystyn istuskelemaan, mutta se on iltapäivisin aurinkoisella säällä niin kuuma, ettei siihen voi mennä. (Meeri)

Osa haastatelluista oli myös aktiivisesti hakeutunut osallistumaan erilaisiin toimintoi- hin: ryhmätoimintaan, retkille ja tapahtumiin. Heidän mukaansa ihmisen itsensä tulee ottaa vastuuta yksinäisyydestään.

\section{Yksinäisyyden torjuminen}

Haastateltavat pohtivat myös yksinäisyyden lievittämistä omassa elämässään. He kokivat tarvitsevansa lisää sisältöä elämäänsä, ihmisten näkemistä enemmän, mahdollisuutta ulkoiluun, tapahtumia. Osa haastatelluista toivoi saavansa ulkopuolelta apua yksinäisyyteensä, osan mielestä yksinäisyyden voi ratkaista vain ihminen itse.

\section{Omavastuisuus yksinäisyydestä}

Osa haastateltavista korosti ihmisen omaa vastuuta elämästään, myös yksinäisyydestään. Haastateltavat kertoivat, mitä olivat omassa elämässään tehneet yksinäisyydestään pääsemiseksi. Joillakin oli tarvittu lasten rohkaisemista, joku oli lukenut lehdestä ilmoituksen alkavasta harrastustoiminnasta tai ryhmästä ja sanonut itselleen, että nyt sinä menet tuonne.

\section{Yksinäisyys on semmoista tarpeettomuuden ja turbuuden tunnetta - ettei ole enää mitään... Mutta kyllä sitä on vain läbdettävä ja keksit- tävä miten tästä eteenpäin. Ei sitä elämäänsä voi aivan toisenkaan varaan jättää, on otet- tava vastuuta itse. (Liisa)}

Osalla haastatelluista lasten tuki yksinäisyyden torjumisessa oli ollut merkittävää. Maire kertoi, että

\section{Lapseni huolehtivat että lähden kotoa jonne- kin - päiviin tulee objelmaa. Tulin mukaan monikulttuuriryhmään, kieliryhmiin jne. Onneksi tyttäreni suositteli.}

Eero oli tyttärensä tuella suunnitellut itselleen viikko-ohjelman, jossa jokaiseen päivään kuului muiden ihmisten tapaamista, mutta hän jatkoi, että en usko että tätä yksinäisyyttä voisi kokonaan poistaa. Lahja puolestaan kertoi, että 
...välillä on niin pitkä aika, ettei tiedä mitä tekisi. Silloin minä soitan lapsille. Ne sanoo, että soitapas vaikka sille ja sille, että saat ajan kulumaan. Ja minä soitan ja pubun niin pitkään kuin ilkeän tai toinen joutaa. Ja keksiibän sitä itsekin usein kaikenlaista tekemistä.

Veera totesi, että kotoa ei kukaan tule hakemaan, itse vain pitää lähteä. Ja Mairen mukaan Pitää olla vahvuutta lähteä itse. Kotonaankin voi tehdä monenlaista. Myös Väinö korosti ihmisen omaa vastuuta ihmissuhteistaan: Jos ibmisellä ei ole ketään - niin silloin pitäisi katsoa peiliin, itsessäkin on vikaa!

\section{Muiden tuki yksinäisyyden torjumisessa}

Suuressa osassa haastatteluja toivottiin apua yksinäisyyteen ulkopuoliselta taholta. Se keneltä apua toivottiin, jäi tarkemmin määrittelemättä. Kuitenkaan yhteiskuntaa ei velvoitettu järjestämään apua, enemmänkin tukea toivottiin ympärillä eläviltä ihmisiltä, järjestöiltä ja vapaaehtoistyöltä. Kannettiin myös huolta yksinäisten ihmisten löytämisestä ja siitä, voidaanko yksinäisyyttä poistaa vain saamalla ihminen osallistumaan. Kotiin kutsumisen kynnyksen todettiin myös nousseen aikaisemmista vuosikymmenistä.

Ibminen pelkää että koti joutuu arvioinnin kohteeksi. (Maire)

Liisa toivoi jonkun tulevan ja kuuntelevan: Kyllä meidän pitäisi kantaa huolta toisistammekin, ei sitä voi aina ajatella, että ybteiskunta... Muutkin haastateltavat toivoivat kotiin tulevaa kuuntelijaa ja keskustelijaa, ei vain ulkoiluttajaa tai tapahtumiin saattajaa.

Suurena ongelmana olivat yksin liikkumisen ongelmat. Elma sanoi,

ettei sitä uskalla yksin läbteä mibinkään, vaikka ei täältä pitkä matkakaan olisi. Pitäisi olla joku hakemassa ja kaverina. Mutta ei se yksinäisyys ainakaan mibinkään bäviä, kun sitä on vain täällä yksinään. Sitä ei uskalla yksin lähteä, kun on niin jäykkä ja kompura ja pelkää, että jos vaikka joku tönäisee... Ennen sitä meni tilaisuuksiin usein yhdessä jonkun toisen kanssa, mutta välillä yksinkin, kuljin täältä linja-autossa. Kun olisi joku joka veisi ulos, läbtisin vaikka talvellakin... ja liukkaammilla voisi ottaa rollaattorin.

Yksin tilaisuuksiin meneminen toi myös haasteita. Maire totesi,

...että olisi joku joka houkuttelisi mukaan! Se on birveän tärkeää. Menin yksin mukaan toimintaan - ei ollut kaveria jonka kanssa men$n \ddot{a}$.

Myös Veera kertoi olevansa vähän arka lähtemään-pitäisi olla joku jonka kanssa menee.

Uusien ystävien saaminen vanhana koettiin vaikeammaksi kuin nuorempana. Lapsuudesta asti tutut ystävät koettiin aarteena, mutta heitä ei enää juuri ollut. Uusissa ystävissä pohdittiin, olisiko yhteisiä kiinnostuksen aiheita tai jos toinen puhuisikin koko ajan itsestään tai valittaisi omia vaivojaan. Toisaalta todettiin, että ei uusien ystävien tarvitse lapsuusystäviä korvatakaan, vaan tapaaminen, keskustelu, ulkoilu ja osallistuminen riittävät.

Meerin mukaan paras lääke yksinäisyyteen on toinen ihminen:

Kyllä sitä voisi käydä semmoisenkin luona, joka on pyörätuolissa... Kyllä se ibminenkin merkitsee, että jos se vieras vain koko ajan valittaa vaivojaan, niin eibän sekään...

Kahdessa haastattelussa arveltiin myös paikallisen kulttuurin olevan sellaista, ettei se tue tutustumista uusiin ihmisiin. Meeri arveli, että olisiko se tämä tämän seudun luonne sellainen, että ne eivät oikein tule kylään?.

Tyynen mielestä on oltava realistinen ja hyväksyttävä yksinäisyys vanhuuteen kuuluvana:

Realistinen tunne - elämä on tätä, luopumista. Yksinäisyyden tunnekin on vain byväksyttä- 
vä-tämä on mun elämää... Alitajuisesti voi kuitenkin toivoa, että tulisijoku... samanhenkinen ja luotettava.

\section{Pohdinta}

Tutkimuksen tarkoituksena oli kuvata Yksinäisyydestä aitoon kohtaamiseen 2016-2018 -hankkeen asiakkaiden omia kokemuksia yksinäisyydestään. Tavoitteena oli tuottaa tietoa yksinäisyyden lievittämiseen tähtäävien interventioiden kehittämiseen. Haastateltavat olivat hankkeen käynnistymisen jälkeen (maaliskuu 2016) ensimmäisen puolen vuoden aikana tavoitettuja, kotona asuvia yli 75-vuotiaita ikäihmisiä.

Haastateltavat itse tai heidän valtuuttamansa henkilö olivat ottaneet yhteyttä alueella käynnistyneen Yksinäisyydestä aitoon kohtaamiseen -hankkeen työntekijöihin pian hankkeen käynnistymisen jälkeen. Siksi voidaan ajatella, että kohderyhmäksi valikoitui ainakin jossain määrin aloitteelliset, itsensä yksinäiseksi usein tai ajoittain kokevat ikäihmiset.

Suomalaisen vanhuspolitiikan keskeisin tavoite on ikääntyneiden kotona asumisen turvaaminen koko elämän ajaksi. Toisena keskeisenä tavoitteena on ikääntyneiden itsenäisen selviytymisen tukeminen arjessaan ja kotihoidon kohdentaminen eniten apua tarvitseville. (STM 2017; Laki iäkkään väestön toimintakyvyn tukemisesta 2012.) Kotona itsenäisesti selviytymistä edistävät esteettömät asuin- ja elinolosuhteet, riittävä toimintakyky ja sosiaaliset suhteet sekä oma turvallisuuden ja elämänlaadun kokemus. Yksinäisyyden kokeminen heikentää elämänlaatua ja turvallisuuden kokemusta, ja sillä on tutkimusten mukaan yhteyksiä myös terveydentilaan (esim. Pitkälä \& Routasalo 2012).

Tässä tutkimuksessa haastatellut edustivat aikaisempien tutkimusten perusteella yksinäisyyteen yhteydessä olevien tekijöiden profiilia: he olivat yksinasuvia, jääneet leskeksi, olivat keskimäärin 85-vuotiaita, terveys- ja toi- mintakyky olivat heikentyneet ja sosiaaliset suhteet olivat harventuneet (myös Tiikkainen 2006; Tiilikainen 2016; Uotila 2011.) He olivat olleet työelämässä kodin ulkopuolella, harrastaneet monipuolisesti ja muuttaneet useita kertoja elämänsä aikana. He olivat joutuneet sopeutumaan erilaisiin asuin- ja elinympäristöihin. Viimeisimmän muuton jälkeen sopeutuminen oli ollut haasteellisempaa omaan elämään liittyvien muutosten vuoksi. Omakotitaloasumisesta joutuu usein luopumaan puolison kuoleman jälkeen. Tässä tutkimuksessa omakotitalossa asuvat olivat jääneet leskeksi vasta hiljattain, kun taas kerrostaloon muuttaneiden puolisoiden kuolemasta oli jo pidempi aika.

Kaikilla haastatelluilla oli ollut puoliso ja lapsia. Sosiaaliset suhteet olivat ikääntymisen myötä muuttuneet, puoliso oli kuollut, lapset muuttaneet kotoa ja perustaneet omat perheensä. Tämä oli osaltaan lisännyt yksinäisyyden kokemusta. Jokaisella haastatellulla oli myös lapsenlapsia, ja he kertoivat suhteensa heihin olevan hyvät. Haastateltavat uskoivat, että saisivat apua tarvitessaan lapsiltaan ja lastenlapsiltaan. Tunne siitä, että saa tarvitessaan apua vähentää yksinäisyyden kokemista (Tiikkainen 2006). Sosiaalisten suhteiden merkitys hyvinvoinnin yhtenä osatekijänä on keskeinen (Levasseur ym. 2010; Dahlberg \& McKee 2014).

Haastateltavat kuvasivat yksinäisyyttään tunteena, joka vain tulee joskus. Se kuvattiin pahaksi oloksi, tarkoituksettomuuden tunteeksi, tyhjyydeksi ja kaipuuksi (myös Tiikkainen 2006; Tiilikainen 2016; Uotila 2011). Yksinäisyys oli tullut elämään vasta ikääntyneenä (myös Luo 2012; Honigh-de Vlaming 2014), jolloin se liittyi elämäntilanteen kasautuviin muutoksiin: leskeytymiseen, terveyden ja toimintakyvyn muutoksiin, asuin- ja elinympäristön muutoksiin ja sosiaalisen saattueen harvenemiseen. Tämän ovat osoittaneet myös useat aikaisemmat tutkimukset (Heylen 2010; Dahlberg \& McKee 2013; Honigh-de Vlaming 2013 ym.; Tiilikainen 2016). Elämä 
oli kapeutunut, ja päivissä oli vain vähän tapahtumia ja kontakteja. Saman ikäiset ystävät ja ystävien tapaaminen ovat Tiikkaisen (2006) tutkimuksen mukaan merkitseviä tekijöitä iäkkäiden sosiaalisen yhteisyyden kokemiselle.

Haastatteluissa tuli esille haastateltavien omia ajatuksia yksinäisyyden torjumisesta. Osa oli ihmisen omaa yrittämistä ja vastuuta korostavia, osa korosti läheisiltä saatua kannustamista ja tukea "kotoa lähtemiseen". Osa oli jo lähtenyt mukaan erilaisiin ryhmätoimintoihin ja tapahtumiin. Lähes jokainen toi esiin myös ajatuksen ulkopuolisen avun merkityksestä, yksinäisten löytämisestä, kotikäynneistä, kulttuuri- ja liikuntatapahtumiin mukaan lähtevistä kavereista. Yhteisöllisyyttä ja muista välittämistä tuotiin myös esille.

Aikuisilla ihmisillä on itsensä tarpeelliseksi kokemisen tarve ja tarve vastavuoroisiin ihmissuhteisiin. Ihmisen tarve on kokea itsensä hyväksytyksi ja saada osakseen rakkautta, kunnioitusta ja arvostusta (Pirhonen 2015). Tämän tutkimuksen tulosten perusteella nousee arvioitavaksi, miten ikääntynyt ihminen muuttuneessa elämäntilanteessaan voi säilyttää nämä elementit elämässään. Haastateltavien elämässä oli ollut rakkautta vähintäänkin läheisiin, he olivat kokeneet olleensa arvostettuja ainakin työelämässä ja olleensa rakentamassa osaltaan yhteiskuntaa ja siten saaneet osakseen kunnioitusta muilta ja myös itsekunnioitusta.

Haasteeksi yksinäisyyden lievittämiseen tähtäävissä interventiossa tulee näiden ikäihmisten uudelleen aktivointi ja elämänpiirin laajentaminen osallistaviin toimintoihin ja sosiaalisiin suhteisiin. Yksinäisyydestä aitoon kohtaamiseen 2016-2018 -hanke jatkuu kehittämällä interventioita yhdessä iäkkäiden ihmis- ten kanssa. Soveltuvia interventioita voisivat olla esimerkiksi tukiystävätoiminta ja vertaistukea korostavat ryhmämuotoiset toiminnot (ystäväpiiri, voimaantumisryhmä, muisteluryhmä). Näiden merkitys on tullut esille aikaisemmissa tutkimuksissa (Savikko 2008; Masi ym. 2011; Jansson 2012; Pitkälä-Routasalo 2012; Mervilä-Puhakka 2015).

Toiminnan tuominen ikääntyneiden lähelle (esim. taloryhmät) ja liikkumisongelmaisten kuljetuspalvelut voisivat tukea osallistumista. Lisäksi toimintoja järjestettäessä tulisi kiinnittää erityistä huomiota yksin saapuvien vastaanottamiseen niin, että he voisivat kokea olevansa tervetulleita ja haluaisivat osallistua jatkossakin. Haasteellista on myös kehittää erilaisia interventioita ja tukimuotoja, joilla voitaisiin vaikuttaa ennalta ehkäisevästi muuttuneiden elämäntilanteiden aiheuttamaan yksinäisyyden kokemukseen.

Tässä artikkelissa kuvataan sellaisia kotonaan asuvia yksinäisiksi itsensä kokevia ikääntyneitä, joilla oli vielä toimintakykyä avun hakemiseen ja joiden elämänlaatua voidaan tukea vapaaehtoistyön ja yhteisöllisyyden avulla. Tällainen interventio auttaa silloin, kun omaa halua yksinäisyydestä selviytymiseen on jäljellä. Haasteena on niiden kotona asuvien yksinäisten ikäihmisten löytäminen, jotka eivät itse jaksa ottaa yhteyttä apua saadakseen ja joilta puuttuu välittävä tukiverkosto.

\section{Yhteydenotto:}

Ritva Kangassalo, TtL, toiminnanjohtaja

Satakunnan Vanhustuki ry

Sähköposti: ritva.m.kangassalo@gmail.com 


\section{Kirjallisuus}

Aronson, J. A. (1994). Pragmatic View of Thematic Analysis. The Qualitative Report, Volume 2(1), 1-3. Haettu 23.3.2017 osoitteesta: http://nsuworks.nova.edu/tqr/vol2/iss1/3.

Burns, N. \& Grove, S. (2005). Practice of Nursing Research: Conduct, Critique, and Utilization. Elsevier Saunders, USA.

Dahlberg, L. \& McKee, K. (2014). Correlates of social and emotional loneliness in older people: $\mathrm{Ev}^{-}$ idence from an English community study. Aging \& Mental Health 18(4), 504-514.

Dickens, A.P., Richards, S.H., Greaves, C.J. \& Campbell, J.L. (2011). Interventions targeting social isolation in older people: a systematic review. BMC Public Health, 11, 647. Haettu 2.2.2017 osoitteesta:

https://bmcpublichealth.biomedcentral.com/articles/10.1186/1471-2458-11-647.

Fokkema, T. \& Knipscheer, K. (2007). Escape loneliness by going digital: a quantitative and qualitative evaluation of a Dutch experiment in using ECT to overcome loneliness among older adults. Aging \& Mental Health 11(5), 496-504.

Hauge, S. \& Kirkevold, M. (2010). Older Norwegians' understanding of loneliness. International Journal of Qualitative Studies of Health and Well-being 5 (1). Haettu 1.6.2016 osoitteesta: http://www.tandfonline.com/doi/pdf/10.3402/ qhw.v5i1.4654? needAccess=true.

Heinrich, L.M. \& Gullone, E. (2006). The clinical significance of loneliness: A literature review. Clinical Psychological Review 26(6), 695-718.

Heylen, L. (2010). The older, the lonelier? Risk factors for social loneliness in old age. Aging and Society 30 (0/7), 1177-1196.

Honigh-de Vlaming, R., Haveman-Nies, A., Heinrich, J.,van`t Veer, P. \& de Groot, L. (2013). Effect evaluation of a two-year complex intervention to reduce loneliness in non-institutionalised elderly Dutch people. BMC Public Health 13, 984. Haettu 4.2.2017 osoitteesta:

https://www.ncbi.nlm.nih.gov/pmc/articles/ PMC4015556/.

Jansson, A. (2012). Psykososiaalisen rybmätoiminnan ybteys iäkkäiden ibmisten yksinäisyyden lievittymiseen ja ystärystymiseen. Tutkimus Ystäväpiiri-toiminnasta. Pro gradu -tutkielma. Jyväskylän yliopisto, liikunta- ja terveystieteiden tiedekunta, terveystieteiden laitos. Gerontologia ja kansanterveys.
Kirkevold, M., Moyle, W., Wilkinson, C., Meyer, J. \& Hauge, S. (2012). Facing the challenge of adapting to a life "alone" in old age: the influence of losses. Journal of Advanced Nursing 69(2), 394-403.

Laine, T. (2015). "Miten kokemusta voi tutkia? Fenomenologinen näkökulma." Teoksessa Aaltola J \& Valli R. (toim.) Ikkunoita tutkimusmetodeibin II. Näkökulmia aloittelevalle tutkijalle tutkimuksen teoreettisiin läbtökohtiin ja analyysimenetelmiin (s. 26-43). Jyväskylä: PS-kustannus.

Laki ikääntyneen väestön toimintakyvyn tukemisesta sekä iäkkäiden sosiaali- ja terveyspalveluista 28.12.2012/980.

Levasseur, M., Richard, L., Gauvin, L. \& Raymond, D. (2010). Inventory and analysis of definitions of social participation found in the aging literature: proposed taxonomy of social activities. Social Science and Medicine 71, 2141-2149.

Luo, Y., Hawkley, L.C., Waite, L.J. \& Cacioppo, J.T. (2012). Loneliness, health, and mortality in old age: A national longitudinal study. Social Science and Medicine 74, 907-914.

Masi, C.M., Chen, H.Y., Hawkley, L.C. \& Cacioppo, J.T. (2011). A meta-analysis of interventions to reduce loneliness. Personality and Social Psychology Review 15(3), 219-266.

Mervilä-Puhakka, K. (2015). Ystäväpiiri-ryhmäläisten toimijuus omatoimisessa rybmässä. Opinnäytetyö. Metropolia Ammattikorkeakoulu, Geronomi AMK. Vanhustyön koulutusohjelma.

Pajunen, E. (2011). Mitä on olla yksinäinen? Tutkimus päijätbämäläisten ikääntyvien yksinäisyydestä. Sosiaalipolitiikan pro gradu -tutkielma. Helsinki: Helsingin yliopisto.

Pirhonen, J. (2015). Tunnustaminen ja sen vastavuoroisuus vanhustyössä. Gerontologia 29(1), 25-34.

Pirhonen, J., Tiilikainen, E. \& Lemivaara, M. (2016). Yksin yhteisössä - tutkimuskohteena tehostettu palveluasuminen. Gerontologia 30(3), 119-130.

Pitkälä, K. \& Routasalo, P. (2012). Ryhmästä apua vanhusten yksinäisyyteen. Lääketieteellinen Aikakauskirja Duodecim 128(12), 1215-16.

Savikko, N. (2008). Loneliness of older people and elements of an intervention for its alleviation. Hoitotieteen laitos, Lääketieteellinen tiedekunta, Turun yliopisto, Annales Universitatis Turkuensis D 808. Haettu 15.1.2017 osoitteesta: http://urn.fi/URN:ISBN:978-951-29-3607-6 
Silverman, D. (2000). Doing Qualitative Research. A Practical Handbook. Sage Publications. USA.

STM (2017). Sosiaali- ja terveysministeriön julkaisuja 2017:6. Laatusuositus hyvän ikääntymisen turvaamiseksi ja palvelujen parantamiseksi 2017-2019. Haettu 21.9.2017 osoitteesta: http://urn.fi/URN:ISBN:978-952-00-3960-8

Tiilikainen, E. (2016). Yksinäisyys ja elämänkulku. Laadullinen seurantatutkimus ikääntyvien yksinäisyydestä. Valtiotieteellisen tiedekunnan julkaisuja 4. Helsinki: Helsingin yliopisto.

Tiikkainen, P. (2006). Vanhuusiän yksinäisyys: seuruututkimus emotionaalista ja sosiaalista yksinäisyyttä määrittävistä tekijöistä. Väitöskirja. Jyväskylän yliopisto, Studies in sport, physical education and health 114 .

Tuomi, J. \& Sarajärvi, A. (2004). Laadullinen tutkimus ja sisällönanalyysi. Helsinki: Tammi.

Uotila, H. (2011). Vanhuus ja yksinäisyys. Tutkimus iäkkäiden ihmisten yksinäisyyskokemuksista, niiden merkityksistä ja tulkinnoista. Väitöskirja. Tampereen yliopisto. Saatavissa: https://tampub.uta.fi/bitstream/handle/10024/ 66801/978-951-44-8553-4.pdf?sequence=1

Vaarama, M., Mukkila, S. \& Hannikainen-Ingman, K. (2014). 80 vuotta täyttäneiden elämänolot ja elinolot. Teoksessa Vaarama, M., Karvonen, S., Kestilä, L., Moisio, P. \& Muuri, A. (toim.), Suomalaisten hyvinvointi 2014 (s. 40-60). Helsinki: THL.

Vanhatalo,U.(2015).Tunteet sanoiksi - Subjektiivisen kokemuksen määrittely ja arviointi. Yksinäisyysverkoston työpaja. Argunenta -hanke, Itä-Suomen yliopisto. Haettu 16.3.2017 osoitteesta: http://www.uef.fi/documents/128231/129484/ Vanhatalo/ea0eb793-658d-4f93-ad22-c61fe72ed89f

Victor, C., Scambler, S. \& Bond, J. (2009). The social world of older people: Understanding loneliness and social isolation in later life. Maidenhead: Open University Press. UK.

Weiss, R. (1973). Loneliness: the experience of emotional and social isolation. Cambridge, Massachusetts: The MIT Press, USA. 